\title{
The Essential Role of Cooperative Law
}

\author{
Antonio Fici*
}

\section{Introduction}

The idea that cooperative law is essential for the development of cooperatives is not new, but only lately is it spreading rapidly within cooperative circles and urging representative entities of the cooperative movement to take concrete actions, as many recent circumstances clearly show. ${ }^{1}$

The International Cooperative Alliance's (ICA) "Blueprint for a Cooperative Decade" of January 2013 includes a general statement, according to which a legal framework "plays a critical role for the viability and existence of cooperatives", and furthermore, an entire chapter dedicated to the cooperative legal framework, where it states the objective "to ensure supportive legal frameworks for cooperative growth". ${ }^{2}$

In the same document, reference is made to the Study Group on European Cooperative Law (SGECOL) and its project to formulate the Principles of European Cooperative Law (PECOL) as initiatives that may help to fulfil that objective by showing through a comparative analysis the way laws apply to cooperatives in different jurisdictions. ${ }^{3}$

Subsequently, in November 2013, the ICA established a new thematic committee within its structure, which is the Committee on Cooperative Law, with the objective of giving independent advice to the ICA on cooperative law, developing proposals to translate the legal principles into cooperative law to ensure the cooperative iden-

* $\quad$ Professor of Private Law at the University of Molise and of Comparative Cooperative Law at the L.U.M.S.A. of Rome.

1. The importance of an adequate legal framework for the development of cooperatives was already emphasized in the United Nations, General Assembly Resolution A/RES/56/114, "Cooperatives in social development", of 19 December 2001, available at <www.un.org/en/ga/search/ view_doc.asp?symbol=A/RES/56/114>, and in the UN Guidelines aiming at creating a supportive environment for the development of cooperatives (see, in particular, point 9 therein) of 2001, available at $<w w w$. un.org/documents/ecosoc/docs/2001/e2001-68.pdf>, as well as in the International Labor Organization's Recommendation No. 193/2002 on the Promotion of cooperatives, available at <www.ilo.org/dyn/normlex/ en/f?p=NORMLEXPUB:12100:0::NO::P12100_ILO_CODE:R193>. See also the Communication from the European Commission $\mathrm{COM}(2004)$ 18 of 23 February 2004, on the promotion of cooperative societies in Europe, available at <http://ec.europa.eu/enterprise/policies/sme/files/ craft/social_economy/doc/coop-communication-en_en.pdf>.

2. See International Cooperative Alliance, Blueprint for a Co-operative Decade, January 2013, p. 4 and Chapter 4, p. 25 et seq., available at: <http://ica.coop/sites/default/files/attachments/ICA\%20Blueprint\%20 - \%20Final\%20-\%20Feb\%2013\%20EN.pdf>.

3. Ibid., p. 30. tity and assessing, advising on, proposing and monitoring changes in cooperative policy at national, regional, international and global level as they affect cooperative law. ${ }^{4}$

Accordingly, cooperative law is a matter more and more debated at cooperative conferences and summits. The most important ones are the following: in 2012, which was a special year for cooperatives, ${ }^{5}$ a small section on cooperative law was organized within the ICA conference in Manchester; ${ }^{6}$ a continental congress on cooperative law took place in 2013 in Brazil within the regional conference of the American region of the ICA; $;^{7}$ and a forum on the update of continental cooperative law was held in 2014 in Colombia within the third Cooperative Summit of the Americas. ${ }^{8}$

At the same time, cooperative institutions are increasingly supporting research projects on cooperative law, including comparative cooperative law. The aforementioned SGECOL represents a prominent example of this, since it has been created thanks to the efforts of an Italian foundation financed by Italian cooperatives and its initiatives, notably the PECOL project, are drawing the attention of similar groups of legal scholars of other continents. $^{9}$

Also in light of this renewed interest towards the cooperative legal theory, this article will seek to demonstrate that recognizing and protecting a distinct identity (prevalently) based on a specific purpose constitute the essen-

4. See <http://ica.coop/en/committee-co-operative-law>. The Committee is composed of a chairperson and two legal experts for each ICA region (Africa, Asia Pacific, Europe, Americas). The author of this article has been designated for the European region.

5. Indeed, the United Nations proclaimed the year 2012 as the International Year of Cooperatives: see United Nations General Assembly Resolution A/RES/64/136, 18 December 2009, available at <www.un.org/ en/ga/search/view_doc.asp?symbol=A/RES/64/136>, and the website of the event $-<w w w$.un.org/en/events/coopsyear/ $>$. Also in the aforementioned Resolution, there is a reference to cooperative law. In fact, the General Assembly "Encourages Governments to keep under review, as appropriate, the legal and administrative provisions governing the activities of cooperatives in order to enhance the growth and sustainability of cooperatives in a rapidly changing socio-economic environment by, inter alia, providing a level playing field for cooperatives vis-à-vis other business and social enterprises, including appropriate tax incentives and access to financial services and markets".

6. The event 'Co-operatives United' took place in Manchester, 29 October - 2 November 2012. The section on cooperative law was organized by Professor lan Snaith, a member of the above-mentioned SGECOL.

7. The President of this congress was Professor Dante Cracogna, and the proceedings have been recently published: see Congreso Continental de Derecho Cooperativo (Guarujá, San Pablo, Brazil, 8, 9 y 10 de octubre de 2013), Buenos Aires, Intercoop, 2014.

8. This summit was held on 2-7 November in Cartagena de India, Colombia. See <www.aciamericas.coop/Invitation>.

9. To learn more about it, cf. Fajardo et al. 2012 
tial function of cooperative (organizational) law. ${ }^{10}$ The article will subsequently discuss, also from a comparative legal perspective, the nature and essence of the cooperative purpose and some related regulation issues. Conclusions include some policy implications of the analysis conducted throughout the article.

\section{The Essential Role of Cooperative Law}

Cooperative law falls within organizational law, thus sharing, in principle, its general objectives. ${ }^{11}$ The issue is, therefore, whether cooperative law performs any specific function relative to organizational law in general or the organizational law of other entities, notably company law.

In a highly inspiring article, Professors Hansmann and Kraakman assign to organizational law the essential role of providing for a form of 'asset partitioning' that could not practicably be established otherwise. ${ }^{12}$ Asset partitioning comprises both the limited liability of the owners or other beneficiaries of the entity (which is the strongest type of what the authors term as 'defensive asset partitioning') and above all "the shielding of the assets of the entity from claims of the creditors of the entity's owners or managers", which is the reverse of limited liability and is termed 'affirmative asset parti-

10. Strictly speaking, cooperative law is the organizational law of cooperative entities - which, depending on the jurisdiction, are termed 'cooperative societies', 'cooperative associations', 'cooperative companies', 'cooperative corporations' or simply 'cooperatives' (which are alternatives that do not necessarily carry legal implications). It thus consists of rules on the definition, formation, organizational and financial structure, allocation of surplus, operations, relations among constituencies and among cooperatives, dissolution, merger, demerger and conversion, variedly distributed throughout a text (or, sometimes, more than one legal text). In a broader sense, cooperative law also comprises the provisions specifically dedicated to cooperatives that may be found in bodies of non-organizational law, such as labor, tax, competition and insolvency law and even civil procedure, property and contract law.

11. In general, these objectives may be pursued either by mandatory rules or by default rules or a combination of both types of rules, which also depends on the nature and type of the objective to be pursued. 'Mandatory rules' are provisions (prohibiting or requiring something) that must necessarily be observed in forming and managing a cooperative (ius cogens). 'Default rules' are provisions that apply to the formation and management of a cooperative only to the extent that their bylaws do not regulate or only partly regulate a certain matter, thus being modifiable in contrast to mandatory rules which may not be derogated (ius dispositivum). The debate on the rationale of both types of rules (e.g. the reduction of transaction costs brought about by default rules), on the optimal/efficient amount of one or the other in the overall regulation of an organizational type and the consequent degree of freedom to be left to bylaws, on the choice between 'majoritarian' default rules and 'penalty' default rules, would not be different for cooperatives from that which takes place for companies (see Kraakman et al. 2009, pp. 20 et seq., also for references to the existing literature on this intriguing subject).

12. Hansmann \& Kraakman 2000, p. 386 et seq. As the authors explain, 'essential' means that for aspects of organizational law other than asset partitioning, workable substitutes could be found elsewhere in the law (ivi, p. 437). tioning'. ${ }^{13}$ As there are various types of defensive asset partitioning, of which limited liability is the strongest, there are various types of affirmative asset partitioning: 'priority with liquidation protection', a weaker type termed 'priority without liquidation protection' and 'exclusive claim on the entity's assets', which is the strongest type of affirmative asset partitioning. ${ }^{14}$

According to Professors Hansmann and Kraakman, the types of asset partitioning that are generally found in a cooperative are priority with liquidation protection and member limited liability, which characterize a business corporation (i.e. a company) as well. ${ }^{15}$ In effect, this corresponds to what the majority of cooperative laws provide for. ${ }^{16}$ This also means that cooperative law does not operate differently from company law in this respect. ${ }^{17}$ Hence, if a specific, essential role of cooperative law is to be found, it must be sought elsewhere.

In the same article, Professors Hansmann and Kraakman address the issue of whether the 'formal separation of control rights from distribution rights whereby those who control the firm are barred from appropriating the firm's net earnings', which is a defining feature of nonprofit entities, is an attribute that these entities may enjoy without the benefit of specially designed organizational law. They conclude that that would not be feasible, thus considering the provision of the non-distribution constraint an essential function of the law of nonprofit organizations. ${ }^{18}$

Of course, the preceding argument refers to nonprofit entities and not to cooperatives, which moreover cannot be considered nonprofit entities, as will be pointed out later in this article. ${ }^{19}$ Nevertheless, it is relevant to cooperative law, to the extent that cooperatives, like nonprof-

13. Hansmann \& Kraakman 2000, p. 393 et seq.

14. Hansmann \& Kraakman 2000, p. 394 et seq.

15. Hansmann \& Kraakman 2000, p. 397.

16. For example, Italian cooperative law awards legal personality to registered cooperatives (Arts. 2523 and 2331 of the Italian Civil Code) and explicitly stipulates that "only the cooperative with its assets is liable for its obligations" (Art. 2518 of the Italian Civil Code) and that "personal creditors of the member may not levy execution on its share or stocks, as long as the society is in existence" (Art. 2537 of the Italian Civil Code). Italian cooperatives are therefore "strong-form legal entities" according to Hansmann and Kraakman's taxonomy.

17. To be sure, the authors add that "liquidation protection from the individual owners themselves" (which involves the right to withdraw) is a third element of asset partitioning which generally characterizes those entities in which asset partitioning comprises the element of priority of claims and liquidation protection from personal creditors of the entity's owner ('strong-form legal entities'): see Hansmann \& Kraakman 2000, p. 435. Indeed, as regards cooperatives, cooperative law is more liberal with respect to withdrawal rights of members; as in many jurisdictions, an ample interpretation of the 'open door' principle may be found, which also regards member exit from the cooperative. However, this does not alter the conclusion in the text, namely, that providing for (a strong type of) asset partitioning should not be considered an essential function of cooperative law.

18. Hansmann \& Kraakman 2000, p. 435 et seq. and see ivi fn. 77 for explanation.

19. Admittedly, a different conclusion might regard social or general interest cooperatives if one shares a certain view of them, as will be pointed out later in the text. Obviously, if social cooperatives are meant to belong to the category of nonprofit organizations, an essential function of social cooperative law would then be that of providing for the nondistribution constraint (or at least, for a weaker form of it). 
it entities, are characterized by a specific purpose, which cooperative law - like the law of nonprofit entities - is expected to recognize and protect.

In other words, when a legal entity, or category of legal entities, has a defining feature that relates to the objective pursued - whether negative (the profit non-distribution constraint that qualifies nonprofit entities) or positive (the mutual purpose that qualifies cooperatives) - the organizational law of that entity, or category of entities, plays the essential role of defining their particular identity in light of the objective pursued.

This applies yet to a greater extent to cooperatives, since their identity is complex and consists of several, at times interrelated, aspects, which do not only pertain to their purpose. $^{20}$

This may be confirmed by a comparison between a cooperative act and a company act, as the former may contain provisions on the organization's objective, the way to fulfil it and other related aspects, which might not appear in the latter. For example, while in the regulation of the European Company (Societas Europaea (SE)) - the European Union law equivalent to a stock company established under national law - nothing is stated with regard to the purpose of an $\mathrm{SE} ;{ }^{21}$ in the regulation of the European Cooperative Society (Societas Cooperativa Europaea (SCE)) - the European Union law equivalent to a cooperative established under national law - the objective of an SCE is stipulated, and accordingly there are specific rules on the allocation of profits. $^{22}$

To put it differently, while there are legal entities that are 'neutral' as regards the purpose pursued, as is the general case with companies, there are other legal entities, including cooperatives (and nonprofit entities, as already observed), that are not 'neutral' in this respect. ${ }^{23}$ Accordingly, company law scholars identify, from and with a view to a comparative analysis, five basic legal characteristics of the company (or business corporation), which are legal personality, limited liability, transferable shares, delegated management under a board structure and investor ownerships, and argue that company (or corporate) law everywhere must, of necessity, provide for them. ${ }^{24}$

As one may observe, they do not include among these characteristics the pursuit of a particular objective, still less profit distribution to shareholders.

By way of contrast, the following pages of this article will manifest the relevance of the entity's objective for cooperative law.

20. An analysis of the aspects of the cooperative identity other than the mutual purpose would exceed the scope of this article; see, however, Fici 2013a and Fici 2013b.

21. See Council Regulation (EC) No 2157/2001 of 8 October 2001 on the Statute for a European company (SE).

22. See Art. 1, para. 3, and Art. 65 et seq., Council Regulation (EC) No 1435/2003 of 22 July 2003 on the Statute for a European cooperative society (SCE).

23. In this regard, I borrow the use of the term 'neutral' from Santini 1973 , p. 151 et seq.

24. In this sense, Kraakman et al. 2009, p. 1.
Stipulating the cooperative identity and preserving its distinguishing features should therefore be considered the primary objective of cooperative law. On a more general level, this is a precondition for a plurality of legal forms to exist within a jurisdiction, for the benefit of the interests served by market pluralism ${ }^{25}$ and more particularly, of the interests of the very founders and members of a cooperative.

Indeed, the rigidity of the cooperative form, which results from its identity being (more or less) carefully defined by law, enhances - within a jurisdiction recognizing a choice among several types of legal entities - a founder's or member's “ability to signal, via her choice of form, the terms that the firm offers to other contracting parties, and to make credible [her] commitment not to change those forms". ${ }^{26}$ If it is true, as some economists maintain, that the cooperative form, under certain circumstances and due to its distinguishing features, has a comparative advantage over for-profit investor-owned business organizations, especially in times of crisis, ${ }^{27}$ and if it is true, as others argue, that the mainstream portrait of the self-interested homo economicus does not always correspond to the reality, which calls for an enterprise form suitable for a different model of individual whose behaviour is (also) driven by social preferences (altruism, reciprocity, justice or equity); ${ }^{28}$ if one agrees on the above, by mandating a precise cooperative identity, cooperative law does not perform a prescriptive function but an enabling function. ${ }^{29}$

This seems evident also with respect to the relationship between the organizational law of cooperatives and other bodies of law, notably tax law and competition law, dealing with cooperatives. Indeed, if organizational law carefully defines the cooperative legal identity, it is possible to justify a particular treatment of cooperatives under tax law. This treatment, in fact, would not be preferential but simply specific to the subject matter that it regulates and therefore perfectly compatible with competition law. ${ }^{30}$

25. On the macroeconomic benefits of a pluralistic market where for profit, cooperative and nonprofit, as well as public, enterprises operate simultaneously, see Stiglitz 2009, p. 345; Birchall 2011, p. 13: "diversity is important because it affects the capacity of a society to respond to uncertain future changes". See also para. 6, ILO Recommendation No. 193/2002, cit.: "A balanced society necessitates the existence of strong public and private sectors, as well as a strong cooperative, mutual and the other social and non-governmental sector", and $\operatorname{COM(2004)} 18$ final, cit.: "today the Commission recognizes the rich variety of enterprise forms in the EU is an important element for the EU economy".

26. In these terms, Kraakman et al. 2009, p. 22

27. Cf., among others, Sanchez Bajo \& Roelants 2011, p. 101 et seq.

28. Cf., also for references, Zamagni 2005, p. 31 et seq.; Borzaga, Depedri \& Tortia 2009.

29. On the possible enabling function performed by mandatory rules, in a similar way to default rules and in a context of plurality of legal forms and freedom of choice among these forms, see Kraakman et al. 2009, p. 22.

30. For this kind of effectiveness of cooperative organization law, see with specific regard to the regulation of the European Cooperative Society the judgment by the Court of Justice of the European Union (EUCJ) of 8 September 2011 (C-78/08 to C-80/08). For a thorough analysis of this decision, see Fici 2013c. 


\section{The Cooperative Purpose}

The organizational purpose is the principal, albeit not exclusive, element of identification of a type of entity and classification of the different types provided for by the law within a given jurisdiction.

There are three general purposes that a legal entity may assume as its ultimate objective: for-profit, not-for-profit and mutual purpose.

The for-profit purpose - which in many jurisdictions is the objective explicitly assigned by law to companies ${ }^{31}$ implies conducting business with the aim of making profits to distribute, afterwards, to the legal entity's participants/owners. Therefore, for-profit entities have a purpose that, in legal terms, has an 'economic' and 'internal' nature at the same time, inasmuch as they are oriented towards their members whose wealth they seek to increase or maximize.

In contrast, the not-for-profit purpose - which in many jurisdictions is the objective explicitly assigned by law to associations and foundations - implies conducting an activity without the aim of making profits to be distributed to the legal entity's members (and/or founders, directors, officers, etc.). This purpose is thus identified in negative terms and merely in opposition to the forprofit purpose. However, it is broader than the for-profit purpose. Indeed, unlike the latter, it is in principle compatible with the legal entity conducting an economic or a non-economic activity, which means that the nature of the activity, whether entrepreneurial or not, is not relevant for conceptualizing not-for-profit (or 'nonprofit') entities. ${ }^{32}$ What is essential for the configuration of the not-for-profit purpose is only that profits arising from the economic activity, if any, are not (and may not be) distributed to the entity's members (and/or founders, directors, officers, etc.). ${ }^{33}$ On the other hand, the

31. If it is true that in general companies are a type of legal entity shaped and made available by legislatures to the public for the pursuit of a forprofit purpose (although exceptions may be found around the world, as, for example, in Peru, where the new Company Act does no longer connect a company to a profit making purpose, but simply to the conduction of business activity; see Torres Morales 2013), legislatures are increasingly enacting special company acts providing for the establishment of companies without a for-profit purpose, including companies pursuing the general interest of the community. Examples include, among others, the 'social enterprise' company, which may be set up under Italian law No. 155/2006 on social enterprise (on which, also for a comparative analysis, see Fici 2009, p. 77 et seq.), the UK community interest company $(\mathrm{CIC})$ and the low-profit limited liability company (L3C) available in some US states, together with the benefit corporation and other similar structures (on which, see Brakman Reiser 2011).

32. This does not exclude that in some jurisdictions not-for-profit entities might explicitly be banned from running an enterprise, while in other jurisdictions, the law of not-for-profit entities might be silent about the activity a not-for-profit entity is permitted to conduct, which may be interpreted in different ways, either as allowing all types of activities or allowing only those not explicitly referred to for-profit entities.

33. Therefore, what qualifies nonprofit entities is the 'non-distribution constraint' and not the fact that they are barred from earning profits, as correctly pointed out by Hansmann 1996, p. 17 et seq., according to which, therefore, a nonprofit entity's members cannot be considered 'owners' since they lack the right to appropriate the firm's residual earnings, which, together with the right to control the firm, is an essential element of ownership. way in which these profits are used may determine the further, and more specific, qualification of a nonprofit entity as a private benefit or a public benefit entity, depending on whether profits are used in the interest of the entity's members or in the interest of beneficiaries who are not members, including the general interest of the community. The purpose of nonprofit entities, therefore, may have either an 'internal' or an 'altruistic' nature, depending on whether these entities aim at benefiting members or non-members. ${ }^{34}$

The mutual purpose is that which characterizes cooperatives and constitutes the focus of the following analysis. ${ }^{35}$ As we shall see, it must be distinguished by both the for-profit and the not-for-profit purpose, although from a theoretical point of view, it shares some traits of both. Consequently, cooperatives are private legal entities that in principle must be distinguished from both for-profit and not-for-profit (or 'nonprofit') entities.

The Rochdale Society of Equitable Pioneers - which was registered on 24 October 1844 and opened its first store on 21 December of the same year in Rochdale, near Manchester, UK - is almost universally regarded as the first structured manifestation of that kind of business organization which the title and substance of 'cooperative' have been referred to until today. ${ }^{36}$

The Rochdale Society began its operations by selling basic foodstuffs to and in the interest of its members. In the declaration of its objects, it was stated that the Society acted "for the pecuniary benefit, and improvement of the social and domestic condition of its members" by performing several economic activities, beginning with "the establishment of a store for the sale of provisions", and including the manufacture of articles for the employment of the unemployed or underemployed

34. This is true in principle, as in theory the pursuit of the general interest might also be compatible with the nonprofit entity acting, though not exclusively, with and for its members, inasmuch as these members pertain to the category of beneficiaries by satisfying the needs of whom the nonprofit entity is meant to pursue an altruistic or general interest purpose. The qualification of a purpose as 'altruistic' does not necessarily entail a positive evaluation of this purpose in terms of social or general welfare. 'Altruistic' here is just opposed to 'internal'. An altruistic purpose may well have or not have a positive impact on the society and the community, which depends on many factors, notably the nature of the beneficiaries and of the interests served by the not-for-profit entity. Therefore, nonprofit entities are not necessarily to be considered 'social' or 'general interest' entities, as the not-for-profit purpose is a pure negative concept, silent in regard to the entity's final orientation. By way of contrast, a (partial) 'social' or 'general interest' orientation may be found (even) in (fully mutual) cooperatives, as the result of their overall regulation, which as we shall see, includes concern for the community in their global purpose.

35. What has been stated in the text does not rule out the possibility to have other, non-cooperative, legal entities pursuing a mutual purpose.

36. Although it is widely accepted that before the Rochdale Society, and not only in the UK, other cooperative-like entities existed already, Rochdale became the home of modern cooperation due to the adoption and formalization by the Society of specific rules of conduct, which definitely contributed to its success and then inspired the cooperative movement and the ICA in the formulation of the cooperative values and principles. Quotations are countless: It may suffice to mention here Gide 1921, p. 13 et seq.; Fauquet 1951, p. 57 et seq.; Digby 1948, p. 9 et seq.; and more recently, among others, Birchall 2011, p. 6, and Sanchez Bajo \& Roelants 2011, p. 115. See also, for basic information, <www. rochdalepioneersmuseum.coop/>. 
members, as well as the purchase or rent of estates of land to be cultivated by the members. ${ }^{37}$

The Rochdale Society's objectives substantially coincide with those that existing cooperative law attributes to cooperatives.

Indeed, although differences of various extent and nature may be found across jurisdictions, ${ }^{38}$ it may be affirmed that cooperatives are conceived by law as entities that conduct an enterprise in the interest of their members as consumers, providers or workers of the enterprise. This organizational objective may be referred to as 'mutual purpose', although it must be clear that only in some countries is this precise formula employed by legislatures and/or legal scholarship to identify the cooperative objective and distinguish it from that of other legal entities. ${ }^{39}$

More precisely, the cooperative objective (or 'mutual purpose') comprises two elements: the ultimate purpose of benefiting members and the conduct of a particular activity to fulfil this purpose, namely, an enterprise with the members as consumers of the goods or services provided by the cooperative enterprise, as providers of the goods or services employed by the cooperative for running the enterprise or as workers of the cooperative enterprise (this determines the 'double quality' of the cooperative members, as will be soon pointed out in the text). ${ }^{40}$

Given that the final purpose of benefiting members may be found in other legal entities as well, namely, in all those that pursue an 'internal' purpose, the specificity of the mutual purpose (and of cooperatives pursuing it) lies in the particular activity that is essential for both the cooperative to achieve its ultimate goal and for its members to satisfy the individual interests behind the establishment of the cooperative. ${ }^{41}$

The development of this particular activity with the members - which may be termed 'cooperative enterprise $^{42}$ - is a characteristic of cooperatives that, when properly understood, significantly contributes to their distinction from companies. In companies, like in any

37. The 'objects' of the Society may be found at <www.rochdale pioneersmuseum.coop/about-us/1844-rule-book>.

38. Cf. Cracogna, Fici \& Henry 2013, where this aspect is usually treated in the third section of the various chapters in Part III. See also Fici 2013c, p. 56 et seq.

39. A 'mutual purpose' is explicitly referred to cooperatives, for example, by Italian law (see Art. 2511, Italian Civil Code). Notwithstanding the fact that Spanish state cooperative law does not employ the expression 'mutuality', this is common in Spanish legal scholarship: see, for example, although critically (as they maintain the crisis of the principle of mutuality), Gadea, Sacristán \& Vargas Vasserot 2009, pp. 37, 417 et seq.

40. On the necessity to identify the purpose of cooperatives by referring not only to their final aim but also to the way in which this aim is pursued, cf. Digby 1948, p. 7: "there is ... something more precise which distinguishes cooperative from other business activities, something which belongs partly to end and partly to means".

41. Notwithstanding they act in the interest of their members, cooperatives, however, are not entirely 'inward' oriented, as will be highlighted in Section 4. More radically, cooperatives that do not act (mainly) in the interest of their members but in the general interest are also found in cooperative legislation (see Setion 5).

42. Or 'cooperative business;' see Fauquet 1951, p. 95. other for-profit entity, the economic activity is simply an instrument for pursuing the entity's final objectives, and it is irrelevant whether this activity is conducted with the members. By way of contrast, cooperatives are formed and exist to run an enterprise that might directly satisfy the interests of their consumer-, provider- or worker-members (who, together, may be referred to as 'user-members', since in fact they are the direct recipients of a service provided by the cooperative enterprise). ${ }^{43}$

Depending on the nature of the members, of their interests and of their relationships with the cooperative, three general types of cooperatives may be identified: consumer cooperatives, producer cooperatives and worker cooperatives.

This threefold classification is not only capable of embracing all the possible forms of manifestation of the cooperative phenomenon, but it is also very useful to analyse it from a legal point of view. ${ }^{44}$

Consumer cooperatives are formed by (natural or legal) persons interested in obtaining certain goods or services and are therefore directed at providing their members with those goods or services by previously buying or manufacturing them. In consumer cooperatives, the cooperative activity in the strict sense (the "cooperative enterprise", as referred to above) is that of transferring goods or services to the members, who are therefore consumer-members, while all other activities (e.g. buying those goods, arranging those services or employing people to do that) are pure means to make it possible. Examples include grocery cooperatives and housing cooperatives but also cooperative banks, among others.

Producer cooperatives are formed by (natural or legal) persons interested in supplying certain goods or services and are therefore directed at acquiring from their members those goods or services in order to transform, process, market or sell them afterwards. In producer cooperatives, the cooperative activity in the strict sense is that of acquiring goods or services from the members, who are therefore provider-members, while all other activities (e.g. processing and marketing goods or employing people to do that) are pure means to make it possible. Examples include agricultural cooperatives transforming milk provided by the members into cheese or bottling and marketing wine provided by the members.

Worker cooperatives are formed by individuals interested in working and are therefore directed at employing

43. This may also be expressed by the distinction between a 'profit undertaking' and a 'service undertaking' as conceptualized by Fauquet 1951, p. 88 et seq.

44. In the non-legal literature, this tripartition is employed, among others, by Birchall 2011, p. 3 et seq. 
them to conduct an enterprise of any possible type. ${ }^{45}$ In worker cooperatives, the cooperative activity in the strict sense is that of employing the members, who are therefore worker-members, while all other activities are pure means to make it possible. Worker cooperatives may be established and found in any sector of the economy, including transportation, construction, professional services, etc. ${ }^{46}$

In contrast, a cooperative that is comprised of only members who provide capital and the qualifying activity of which consists (mainly or exclusively) in employing this capital for running a profitable enterprise that might remunerate the capital would not be conceivable. ${ }^{47}$ Cooperative law is clear in excluding this possibility, which seems obvious as it corresponds to what companies do in pursuing their for-profit purpose. Cooperatives, unlike companies, are not means for remunerating and accumulating capital, but for satisfying needs of a different type.

From a theoretical point of view, however, the above raises the question of whether companies may be considered a particular type of producer cooperatives, namely, 'capital cooperatives'. Answering in the affirmative, indeed, would blur the distinction between cooperatives and companies, as well as between the mutual purpose and the for-profit purpose.
The nature of the cooperative purpose affects, among other things, the nature of cooperative membership. ${ }^{48}$ In principle, members of a cooperative may only be those who are interested in and can make use of the particular service provided by the cooperative, namely, consumers, providers or workers of the cooperative enterprise. $^{49}$

As a result, in cooperative theory, it is affirmed that a cooperative's members possess a 'double quality', being at the same time both members of the cooperative entity and users of the cooperative enterprise; or similarly, an 'identity principle' is invoked in order to point out that in a cooperative, members (of the organization) and users (of the enterprise performed by the organization) are identical, which is not necessarily the case in other business organizations. ${ }^{50}$

This aspect appears per se sufficient to successfully oppose the theory according to which - at least as far as ownership is concerned - cooperatives are not dissimilar from companies or rather that companies are a particular type of producer cooperative, i.e. 'lenders' cooperatives' or 'capital cooperatives'.

In his outstanding book on the ownership of enterprise, Professor Henry Hansmann - moving from the assumptions that a firm's owners "are those persons who share two formal rights: the right to control the firm and the right to appropriate the firm's profits, or residual earn-

48. Cooperative law normally requires a minimum number of members to establish a cooperative. A trend may be observed in cooperative law to reduce this minimum number, which in Europe, for example, is currently of three members on average. Strikingly, in some jurisdictions, a cooperative with a sole member is permitted (as happens in Finland in virtue of the new Cooperative Act No. 421/2013: see Henrÿ 2013; but see also van der Sangen 2013, pointing out that under Dutch law, a cooperative can survive with one single member), which seems a contradiction in terms as cooperatives unlike companies cannot be viewed as mere instruments to separate a patrimony and moreover cannot by definition be controlled by a single person, unless we imagine a cooperative controlled by a cooperative in order to create a homogeneous cooperative group (see Fici 2014, p. 145). On the other hand, there is no reason why a cooperative should have a higher minimum number of members than a company, at least under general cooperative regulation, because special acts on particular types of cooperatives might opportunely provide for a higher minimum number (e.g. in cooperative banks).

49. Cooperatives are, therefore, made up of user-members. To protect this profile, cooperative law usually allows cooperative bylaws to provide for requirements for obtaining and maintaining the status of member. Accordingly, the circulation of the status of a cooperative member is not free as the circulation of company shares usually is. Cooperatives, unlike companies, are therefore normally characterized by intuitus personae. On the other hand, the admissibility of non-user-members, including investor members, in a cooperative is a controversial issue, differently solved by national cooperative laws: see Fici 2013b, p. 47 et seq.

50. See Münkner 1974, p. 31 et seq.; Münkner 1982, p. 52; and Münkner \& Vernaz 2005, p. 140. This should also explain the qualification of cooperatives as 'self-help organizations' (see ICA Statement under 'values'), given that they are established by members to satisfy their common needs. However, this formula seems too generic, since all organizations, including companies, are established to satisfy member needs (in case of companies, to invest their capital), although, of course, the nature of a member's needs in companies and in cooperatives is different, which, among other things (members' joint control, democracy, 'outward' orientation as a consequence of the 'external' allocation of own resources, etc.), contributes to determining the 'social function' of cooperatives as compared to companies, as we shall also point out later in the text. 
ings"; that a firm's patrons are "all persons who transact with a firm either as purchasers of the firm's products or as sellers to the firm of supplies, labor, or other factors of production"; and that "nearly all large firms that have owners are owned by persons who are also patrons" 51 comes to the conclusion that "the conventional investorowned firm is nothing more than a special type of producer cooperative - a lenders' cooperative, or capital cooperative". ${ }^{52}$ Indeed - like in a typical producer cooperative, for example, a cheese cooperative owned by farmers who supply the factory with raw milk - in a capital cooperative, owners are those persons who supply a particular factor of production, namely, capital. In Hansmann's words, "the members of the capital cooperative each lend the firm a given sum of money, which the firm uses to purchase the equipment and other assets it needs to operate". ${ }^{53}$

Indeed, if one considers the firm's ownership structure alone and adopts general concepts of firm owners and patrons, one may correctly conclude that investorowned companies cannot be distinguished from cooperatives, that the cooperative is the general conceptual category of patron-owned firms and that conceptually companies pertain to the category of cooperatives, representing, more precisely, a particular species of producer cooperatives. ${ }^{54}$

This, however, fails to consider the above-described double quality of cooperative members, which a company's participants, i.e. shareholders, do not possess.

Indeed, shareholders, as such, do not make use of the company's enterprise and do not directly benefit from it. The shareholder's relationship with the company only takes place at the organizational level and does not involve a parallel transaction for the exchange of goods or services or the execution of work. In other words, shareholders are only owners of the company and not also users of its enterprise. ${ }^{55}$

The provision of capital is the 'price' they pay to become owners and not the object of an additional transaction with their company. ${ }^{56}$

By way of contrast, cooperative members - or 'cooperators' as they are referred to at times - are direct users

51. Hansmann 1996, p. 11 et seq.

52. Hansmann 1996, p. 11.

53. Hansmann 1996, p. 14. This contention is shared by Kraakman et al. 2009, p. 15.

54. Accordingly, at a Conference held in Venice in March 2012, Henry Hansmann gave a presentation with the evocative title of 'Nearly All Firms Are Cooperatives', where he reduced all firms and saved nonprofit ones which do not have owners to the concept of cooperative. See now Hansmann 2013.

55. Obviously, this does not mean that a company and its shareholders do not and may not enter into transactions between each other, but only that these transactions would fall outside the institutional purpose of a company and consequently interest company law only to the extent that they might lead to a conflict of interests (between the company and the shareholders that are parties to the transaction) which may be detrimental to the pursuit of the company's objective and therefore require specific rules of company law to deal with it.

56. By way of contrast, Hansmann 1996, p. 14, holds that members' contribution of capital is, in effect, loans, although the fact that the fixed interest rate paid on loans from lender-members is typically set at zero obscures this fact. and beneficiaries of the cooperative enterprise. The cooperative enterprise serves directly their needs and not only indirectly (by capital remuneration and/or share appreciation) as happens in companies with regard to shareholders. ${ }^{57}$

Cooperative members undertake two types of relationships with the cooperative ${ }^{58}$ : the organizational relationship which stems from their status of members (normally as contributors of capital as well) and the transactional relationship which derives from their being providers, consumers or workers of the cooperative enterprise. The two relationships are connected; in many jurisdictions, they may even be subject to the same body of law (i.e. cooperative organizational law) and be hardly distinguishable one from the other, but they never overlap entirely.

In any event, even if one does not want to emphasize this double relationship between the cooperative and its members or maintains that it is not substantially different from that which exists between a company and its shareholders, the possibility would remain of drawing clear borders between cooperatives and companies - or, if one prefers, between cooperatives and 'capital cooperatives'.

Indeed, as already stated, the legal identity of cooperatives is not limited to the functional aspect and the related ownership structure, but includes governance and financial aspects that are typical of cooperatives and cannot be found in other business organizations. The democratic principle 'one member, one vote', which ensures the democratic control of the organization by its members (and excludes the control by only one member or by a minority of members) and moreover precludes the external control of a cooperative; the partial 'outward' orientation, which makes meeting the members' needs the main but not the exclusive mission of a cooperative; and the variability of capital and the 'open-door' principle, which permits third parties to share the utility a cooperative is able to produce all definitely differentiate cooperatives from companies and determine, as we shall

57. The role of the enterprise is, therefore, diverse in cooperatives and in companies. As Charles Gide puts it, "it is only in a co-operative association that production is organized solely with the view of satisfying needs" (Gide 1921, p. 12), whereas in companies, production is a means for making profits. In his famous article concluding for the absence of any difference between cooperatives and companies from an economic point of view, even Pantaleoni 1898, p. 208, admits that "at most, the difference that exists between a cooperative and a different type of enterprise is the same as that which exists between a person who directly produces what he needs, and a person who produces that indirectly for himself, namely, by exchanging a product in the manufacturing of which he specialized" [translation by author]; although, admittedly, in this article this conclusion is limited to consumer cooperatives and explicitly refused for producer cooperatives, "They have to sell their products to the public. And this breaks off any further discussion" [translation by author] (ibidem). See also Birchall 2011, p. 2, giving the same emphasis as in the text to the fact that cooperatives are owned by those who benefit directly from its activities, and Fauquet 1951, p. 88 et seq.

58. Or, if one wants to adopt a slightly different view shared by some jurisdictions, one must state in a partially different way that the relationship between the cooperative and its members comprises both an organizational relationship and an exchange relationship. 
observe, their unique 'social function' as compared to other business organizations, notably for-profit stock companies.

\section{Cooperative Transactions and Their Regulation}

Implementation of the mutual purpose involves, as stated, transactions between the cooperative and its members for the exchange of goods or services or for the execution of work, depending on the type of cooperative, whether a consumer, provider or worker cooperative.

These transactions play a distinct role among all the transactions that are necessary for a cooperative to act as a firm in the market. They are the very transactions through which cooperatives fulfil their typical purpose and cooperative members satisfy their individual interests: the raison d'être of a cooperative for those who decide to establish it.

This is the reason why in cooperative legal theory, these transactions must be kept separate from all others, beginning by giving them a distinct name, as some cooperative laws appropriately do, using formulas such as 'cooperative acts' or 'mutual relationships' ${ }^{59}$ Hereafter, this article will refer to them as 'cooperative transactions', which is consistent with the previous denomination of 'cooperative enterprise' given to the economic activity with and in the interest of the members, which constitutes the principal element of the cooperative objective.

Due to their particular function within a cooperative, cooperative transactions require a specific regulation.

A matter that needs careful consideration is, for example, whether and to what extent a cooperative and its members are (or must be) obligated to transact with each other. It is evident, indeed, that a cooperative not engaging in transactions with its members would not fulfil its institutional purpose and would not satisfy the interests of its members. By the same token, a member not participating in cooperative transactions would not allow a cooperative to fulfil its purpose (and indirectly, the other members to satisfy their interests). Therefore, freedom to transact is incompatible with the concept of a cooperative, especially if the cooperative is given such

59. 'Cooperative act' is a term and a concept diffused in the Latin American legal environment, although it may also be found in the Spanish jurisdiction where, more precisely, reference is made to the 'cooperative activity' (actividad cooperativizada) (see Fajardo 2013). These transactions are termed 'mutual relationships' (rapporti mutualistici) in the Italian legal system. In the German legal scholarship, they are known as 'purpose transactions' (Zweckgeschäfte) as opposed to 'countertransactions' (Gegengeschäfte), i.e. "transactions necessary to make purpose transactions possible, e.g. in the case of consumer cooperatives, purchasing goods from wholesalers or producers in order to sell them to members, and in the case of marketing cooperatives, selling the products of the members to wholesalers. Such counter-transactions are by their nature usually transactions with non-members in a broader sense and are not relevant in the discussion of whether or not business with non-members is allowed" (in these terms, Münkner 2013). a freedom. On the other hand, the law can hardly state the precise extent of the obligation to transact, which implies that in principle, a sound solution to this problem would be to leave to cooperative bylaws the freedom to regulate the matter, by making it, however, compulsory for them to provide for the minimum extent to which cooperative members are obligated to transact with the cooperative or at least for the manner in which it is to be determined. This corresponds approximately to the cooperative practice, especially in agricultural cooperatives where the problem of inactive members is probably perceived more than in other types of cooperatives (for example, large consumer cooperatives, such as cooperative banks), and to the solution adopted by some cooperative laws. ${ }^{60}$ This issue may also be dealt with by awarding cooperatives the right to expel inactive members and members the right to withdraw from the cooperative if the cooperative refuses to transact with them without reasonable grounds.

The cooperative's obligation to treat members equally in the conclusion and execution of cooperative transactions, as found, for example, in Italian cooperative law, ${ }^{61}$ is a significant provision not only in general terms but also in dealing specifically with the preceding issue. Indeed, this obligation indirectly protects a member's right to transact with its cooperative, since the cooperative could not be excused for not transacting with that member if the impossibility to transact was due to an excessive, and therefore unequal, amount of transactions with other members (or, which would be worse, with non-members).

Another fundamental legal issue raised by cooperative transactions is that of the potential application to them of bodies of law regulating those types of market transactions which they resemble and to which they would undoubtedly be subjected to had they been carried out outside a cooperative. Is contract law (notably, consumer contract law) applicable to the exchange of goods and services between a consumer or a producer cooperative and their members? And is labour law applicable to the relationship between a worker cooperative and its worker members? Or does cooperative organizational law regulate them exclusively? Obviously, the point is yet more delicate when mandatory rules of contract or labour law are considered, such as those protecting consumers against defective products or awarding workers the right to strike.

If on the one hand to subject cooperative transactions to ordinary contract or labour law would imply ignoring their specificity as compared to market transactions, on

60. See, for example, Art. 15, par. 2, lit. b, of the Spanish Cooperative Act, which stipulates the members' obligation to transact with the cooperative to the minimum extent provided for by its bylaws. However, as Gide 1921, p. 63, warns, "the loyalty of members is a matter of education, not of coercion". Binding and uniform agreements between a farmer cooperative and its members, which award the cooperative the power to define quantity, quality and other terms of the exchange relationships, are one of the attributes of the so-called new generation cooperative model (see Chaddad \& Cook 2004, p. 355; more recently, Chaddad 2012, p. 456).

61. See Art. 2516 of the Italian Civil Code. 
the other hand there may be rights of cooperative members that deserve protection in all cases.

The matter is complex and differently handled by jurisdictions and legal scholarships. Solutions should be expected to be in line with the concept of cooperative transactions that is adhered to. ${ }^{62}$ In principle, cooperative law and cooperative bylaws should be given precedence over other possible sources in the regulation of cooperative transactions, which therefore should only apply residually and additionally to fill the gaps left by cooperative law and cooperative bylaws. In any event, one must not forget that private autonomy (i.e. the power of self-regulation by bylaws) and cooperative law remain subject to sources of a higher ranking in the hierarchy of legal sources, which means that, for example, the regulation of cooperative transactions cannot be such as to violate fundamental rights recognized by national constitutions or international treaties and conventions.

\section{The Cooperative Activity with Non-Members}

Once precise concepts of 'cooperative enterprise' and 'cooperative transactions' are adopted and they are employed to distinguish cooperatives from other business organizations, the issue arises of whether a cooperative can engage in transactions with non-members for the provision of goods, services or jobs of the same kind as those provided to members.

It must be clear that this problem only exists with reference to 'cooperative transactions' as outlined above and not to all the other transactions necessary for a cooperative to make cooperative transactions possible and to operate in the market as a firm, which by their very nature are transactions with non-members (even if they accidentally involve persons who are members of the cooperative). Hence, it must be inquired whether a consumer cooperative can sell goods or services (of the same kind as those provided to members) to non-members, a producer cooperative can buy goods and services (of the same kind as those supplied by members) from nonmembers or a worker cooperative can employ nonmembers.

In principle, this cooperative activity with non-members (or non-member cooperative transactions) contradicts the essence of a cooperative, is against its nature and purpose and clashes with the image of the cooperative as a user-owned and not as an investor-owned organiza-

62. In the sense that in jurisdictions where these transactions are seen as 'cooperative acts', their being subject to ordinary contract or labour law should be excluded, given that these cooperative acts are not 'contracts' or 'labour relationships' but 'cooperative acts'. On the other hand, in jurisdictions emphasizing the double quality of cooperative members, as members of the organization and users of the cooperative enterprise, it is more probable that cooperative transactions are considered, at least residually and additionally, subject to ordinary contract and labour law. tion. As Charles Gide, one of the pioneers of the theory of consumer cooperatives, puts it, "there is no doubt that selling to the public is outside the sphere of cooperation. One might even say that it is outside its very definition, because when a society sells to the public it can no longer say that its object is 'to provide for the needs of its members"'. ${ }^{63}$

However, in practice, cooperatives have been acting in this way. As Charles Gide recalls, even the Rochdale Society would sell to the general public. ${ }^{64}$ And in theory, prohibiting all transactions with non-members would hamper the expansion of the cooperative business, the capacity of the cooperative to face sudden contractions of the member demand or offer of goods, services or work and its potential willingness to allow more people to enjoy the benefits (not only of an economic type) it is able to produce, that is, to attract new members.

This is probably the reason why cooperative laws usually do not prohibit non-member cooperative activity, but subject it to particular limits and conditions, in order to prevent a cooperative from acting as an ordinary business organization on the market, which 'exploits' the general public by making profit from them. ${ }^{65}$ As a result, usually cooperatives are not obligated by law to be 'fully mutual' but only 'mainly mutual', which is to say, to act prevalently with their members. ${ }^{66}$ In addition, in some cooperative laws, measures are taken to make sure that cooperative members do not, at least directly, benefit from the cooperative activity with nonmembers, which is what a company's shareholders do (or, at least, aim to do!).

Such measures include the compulsory allocation of profits from non-member cooperative transactions to indivisible reserve funds, ${ }^{67}$ the obligation to treat nonmembers on equal terms as members ${ }^{68}$ and the obligation to admit to membership those non-members involved in cooperative transactions (provided that they meet the requirements laid down by the cooperative

63. Gide 1921, p. 49 et seq., which goes on to mention German law in force at that time prohibiting it under severe penalties.

64. Gide 1921, p. 50, which however explains that the Society adopted, as an ingenious rule, the method of giving the non-members a bonus or dividend at half the rate of that returned to members, placing the surplus in the reserve fund.

65. Cf. Cracogna, Fici \& Henry 2013, where this aspect is usually treated in the third or fourth section of the various chapters in part III.

66. In some jurisdictions, this is an obligation only under tax law, which means that under organizational law, cooperatives may freely act with non-members, which is not a sound solution in principle, on the basis of the arguments put forward in the text. In other jurisdictions, where a minimum of mutuality is required for all cooperatives, the different degree of mutuality only affects the tax treatment of cooperatives. A very meticulous identification of the limits within which activity with non-members is permitted may be found in Japanese law: see Kurimoto 2013.

67. Which, however, is a solution that makes sense only if these reserves are indivisible also upon dissolution, because otherwise, members would equally profit from non-member transactions although at a later stage, i.e. at cooperative dissolution.

68. Which, however, is a solution that does not transmit adequate incentives to non-members to become members, unless of course they are specifically interested in holding governance rights. 
bylaws), which, for example, is a general rule in French cooperative law. ${ }^{69}$ In contrast, cooperative laws that simply allow cooperative by-laws to admit activity with non-members without setting limits to this power do not protect this particular aspect of cooperative identity.

\section{The Social Function of Cooperatives and the General Interest Cooperatives}

Cooperatives pursue a purpose that in our classification is 'internal', given that members benefit from a cooperative's activity and its results. In this specific aspect, therefore, cooperatives are not different from for-profit companies. How can the social function that some constitutions (around the world and in different ways) attribute to cooperatives be, then, explained? ${ }^{70}$ Why are there constitutional provisions obligating legislatures to promote cooperatives? ${ }^{71}$ How can it be that cooperatives are widely regarded as a means of promoting human rights and sustainable development? ${ }^{72}$ Why and how should they contribute to a better world? ${ }^{73}$

Indeed, in addition to the general statements that may be found in the ICA principles, in particular in the 5th, 6th and 7 th principle, ${ }^{74}$ the social function of cooperatives stems from a number of elements. ${ }^{75}$

69. See Art. 3 of Law 47/1775. See also Art. 23 of Mexican general cooperative law of 1994 and Gide 1921, p. 52

70. Explicitly in this sense, Art. 45 of the Italian Constitution.

71. A prominent example is represented by the Portuguese Constitution, which contains a considerable amount of provisions on cooperatives and their promotion by the state. References to cooperatives and a state's obligation to promote them are very common in the constitutions of Latin American countries. See also the recent 97th amendment to the Indian Constitution, making the establishment of cooperatives a fundamental right of citizens.

72. See Henrÿ 2012.

73. See fn. 5 above. It is also worth noting that the law of the Republic of Korea obliges the central government to designate a Cooperatives Day and a Week of Cooperatives every year: see Jang 2013.

74. The 5th ICA principle is relevant in this regard as it includes non-members among the potential beneficiaries of education and training and the general public of information campaigns, the 6th ICA principle inasmuch as it foresees a sort of solidarity among cooperatives and the 7th ICA principle because it explicitly envisages the use of resources in favour of the community.

75. This article, of course, cannot give an account of all the existent cooperative laws around the world and the variety connoting them. There are jurisdictions where cooperatives are not regulated by law so as to give them a 'social function' and where cooperatives are prevalently considered pure instruments of economic activity among others. There are jurisdictions where 'one member, one vote' is only a default rule; where cooperatives are not obligated to contribute to other cooperatives, the cooperative movement; where the interest of third parties to become members of a cooperative is not protected by law; etc., as we have pointed out in other work (see Fici 2013a). Thus, what is stated in the main text is not to obliterate the differences that may be found across cooperative laws and cooperatives around the world, which are also the result of a different level of implementation of the ICA principles and of a different vision of cooperatives and their role in the economy and the society.
First of all, it must be recalled that cooperatives are not for-profit investor-owned entities, but organizations whose aim is to satisfy member needs other than capital remuneration and appreciation (although the cooperators' needs may have an economic nature). Moreover, these needs may be fundamental needs related to human personality, such as work and housing, which are not attended to by the market and for-profit players therein. Secondly, the intrinsic sociality of cooperatives derives from their governance structure, where, among other things, persons count more than capital and all count equally, given the democratic principle 'one member, one vote', which makes the control of a cooperative by a single member or a minority of members impossible and thus ensures that all the members may control the cooperative, thereby stimulating effective member participation in the management of the cooperative and consequently in the economic life of a country. ${ }^{76}$

In addition, the 'open-door' principle, if effectively implemented, is a very important instrument of socialization of the economic results of an enterprise. ${ }^{77}$

Thirdly, cooperatives have a social function because their regulation - following the ICA principles - usually provides for certain 'external' destinations of their own resources in favour of non-members (or future members), other cooperatives and the cooperative movement and the community at large. ${ }^{78}$

This per se attenuates the 'internal' nature of the purpose that cooperatives have in common with companies. Only to the extent that cooperative law provides for these elements and protects them - which is to say, stipulates and preserves a distinct cooperative identity - is it possible to conclude that cooperatives have a social function as compared to other business organizations, in particular for-profit investor-owned companies. Otherwise, in this particular regard, the cooperative difference would almost dissolve ${ }^{79}$ and state promotion of cooperatives would become hardly justifiable.

Notwithstanding the above, cooperatives remain entities oriented towards their members, whose interests they (mainly) aim to satisfy. Cooperative members are 'owners' in Hansmann's sense, since they hold both the right to control the firm and the right to appropriate the firm's benefits. ${ }^{80}$ Therefore, cooperatives cannot be con-

76. In some cooperative laws, cooperative bylaws are empowered to award more than one vote to members. Plural voting may be considered still compatible with the cooperative identity as long as it does not lead to the control of the cooperative by a sole member or a minority of members and is not based on their capital contribution but on other criteria, like the volume of a member's cooperative transactions with the cooperative (for a discussion of this point, see Fici 2013b, p. 50 et seq.).

77. On this principle and its 'social' impact, see Fici 2013b, p. 55 et seq.

78. On these 'external allocations', which contribute to the social function of cooperatives, see Fici 2013b, p. 45 et seq.

79. In which case, those who deny the cooperative difference - especially on the basis of the fact that cooperatives, like companies, promote the economic interest of members, their 'egoism' - such as Pantaleoni 1898, would not be mistaken.

80. In a cooperative, however, the firm's benefits are appropriated by members in a particular way, i.e. as 'cooperative returns' or 'patronage refunds': on this concept, which presupposes that of 'cooperative surplus', see Fici 2013 b p. 39 et seq. 
sidered nonprofit entities, given that the beneficiaries of the entity are the very people who control it. ${ }^{81}$ Cooperatives have a social function, but are not (mainly) altruistic or solidaristic organizations. They are distinct from nonprofit firms and in particular from 'social enterprises' as recently provided for in some jurisdictions. ${ }^{82}$

This conclusion, however, holds true only for the traditional type of cooperative that corresponds to the Rochdale Society's norm and to the model contemplated by the ICA principles and has occupied these pages until now. In contrast, a different conclusion applies to a new (and additional) general type of cooperative, which legislatures around the world - beginning, at least to the author's knowledge, in Italy with Law No. 381/1991 on social cooperatives ${ }^{83}$ - are increasingly introducing into their legal systems.

Italian social cooperatives - like French collective interest cooperatives, Spanish social initiative cooperatives and Portuguese social solidarity cooperatives, to mention but a few - "pursue the general interest of the community" (as explicitly stated by the above-mentioned Italian Act) and not the interest of their members.

They are not mutual cooperatives but general interest cooperatives. ${ }^{84}$

The tendency to detach cooperatives from the pursuit of a pure internal purpose may also be found in the legislation on 'social enterprises', where it is generally admitted that (also) cooperatives may assume the legal status of social enterprises, provided that they have a general interest objective and meet other general requirements. ${ }^{85}$

Cooperatives, therefore, are no longer necessarily linked to a mutual purpose, and the law increasingly admits their pursuing the general interest. Cooperative legal theory has to recognize this fact and starts also dealing with general interest cooperatives, which relative to

81. See, in this sense, Hansmann 1996, p. 17

82. See for references footnotes 30 and 81.

83. Admittedly, the UK community benefit society (BenCom), as currently provided for by IPSA 1965, has a longer history than the Italian social cooperative of 1991. However, the BenCom is not a cooperative in the strict sense, since the law does not require it to have a cooperative structure and moreover conceives it as an alternative to the bona fide cooperative (a society may be registered under IPSA 1965 either as a bona fide cooperative society or as a BenCom). In fact, it is a controversial issue whether BenComs must operate on a 'one member, one vote' basis. The author is grateful to Michael Cook from the Federal Conduct Authority (FCA) and Ian Snaith for having provided him with more details on this point, which, however, it is not possible to present and discuss in this chapter.

84. Admittedly, this is a conclusion that may partially vary depending on the jurisdiction concerned. In particular, while in some jurisdictions it is clear that social cooperatives, or similar, must exclusively pursue the general interest, in other jurisdictions, social cooperatives, or similar, are more precisely conceived as cooperatives acting mainly (but not exclusively) in the general interest, which means that they can benefit their members, although this must not be their primary objective.

85. Examples include Finnish Act No. 1351/2003, the already-mentioned Italian Act No. 155/2006 and the UK CIC Regulation. mutual cooperatives presents different problems of regulation, due to their distinct objective. ${ }^{86}$

\section{Conclusions}

This article has focused on the specific, essential function of cooperative (organizational) law, which is to recognize and preserve the distinct identity of cooperatives relative to joint-stock (for-profit) companies. This function of cooperative (organizational) law is 'essential' inasmuch as workable substitutes for it could not be found elsewhere in the law and is 'specific' in comparison to the general, essential function(s) of company law. It is this essential role that justifies the renewed interest of the cooperative movement towards cooperative law and cooperative legal research and theory. Indeed, a definite, distinct legal identity of cooperatives is increasingly being seen by the cooperative representatives as a precondition for the cooperative defence and growth, also in light of the fact that a particular legal identity may justify a specific policy regime of cooperatives, especially under tax law.

Once that the distinguishing traits of cooperatives are recognized by law, it becomes easier for cooperative advocates to invoke policy measures in favour of cooperatives and for the state to justify these policies in light of the principle of equal treatment. A specific treatment of cooperatives, in fact, could not be considered preferential if the very legislator considers cooperatives as business organizations of a particular type.

Obviously, the questions remain open, among others, of what elements shape the cooperative identity, of the role that the principles of the International Cooperative Alliance may have in this respect and whether there is a need for more uniformity in the regulation of cooperatives and in the identification of their essence across jurisdictions. This article has highlighted the role of the 'mutual purpose' in shaping the cooperative identity and has explored some issues related to the implementation of this particular institutional objective. It has also emphasized a new legislative tendency, namely, to detach cooperatives from the pursuing of a mutual purpose and to provide for cooperatives pursuing the general interest of the community. This tendency is not surprising if one considers the 'social function' that already connotes mutual cooperatives.

\section{Bibliography}

J. Birchall, People-Centred Businesses. Co-operatives, Mutuals and the Idea of Membership, London, Palgrave MacMillan 2011.

86. For example, the governance structure of a general interest cooperative should be designed by law in coherence with its purpose which is external in character, e.g. by giving voice to beneficiaries who are not members or, more in general, to representatives of the community within which the cooperative operates. 
C. Borzaga, S. Depedri \& E. Tortia, "The Role of Cooperative and Social Enterprises: A Multifaceted Approach for an Economic Pluralism”, Euricse Working Papers, No. 00/09, 2009, available at <www.ssrn.com>.

D. Brakman Reiser, "Benefit Corporations - A Sustainable Form of Organization?", 46 Wake Forest Lam Reviem, 2011, p. 591 et seq.

F. Chaddad, "Advancing the Theory of the Cooperative Organization: The Cooperative as a True Hybrid", 83 Annals of Public and Cooperative Economy 4, 2012, p. 445 et seq.

F. Chaddad \& M. Cook, "Understanding New Cooperative Models: An Ownership-Control Rights Typology", 26 Reviem of Agricultural Economics 3, 2004, p. 348 et seq.

D. Cracogna, A. Fici \& H. Henrÿ (eds.), International Handbook of Cooperative Lam, Heidelberg, Springer 2013.

M. Digby, The World Co-operative Movement, London, Hutchinson's University Library 1948.

G. Fajardo, A. Fici, H. Henrÿ, D. Hiez, H.-H. Münkner \& I. Snaith, "New Study Group on European Cooperative Law: 'Principles' Project”, Euricse Working Paper Series, n. 24/12, 2012, available at <www.ssrn.com>.

G. Fauquet, The Co-operative Sector [a translation of the fourth French edition published in 1942], Manchester, Co-operative Union Limited 1951.

A. Fici, "Cooperatives and Social Enterprises: Comparative and Legal Profile", in B. Roelants (ed.), Cooperatives and Social Enterprises. Governance and Normative Framemorks, Brussels, CECOP 2009, p. 77 et seq.

A. Fici, "Cooperative Identity and the Law", 24 European Business Lam Reviem 1, 2013a, p. 37 et seq.

A. Fici, "An Introduction to Cooperative Law", in D. Cracogna, A. Fici \& H. Henrÿ (eds.), International Handbook of Cooperative Lam, Heidelberg, Springer 2013b, p. 3 et seq.

A. Fici, "The European Cooperative Society Regulation", in D. Cracogna, A. Fici \& H. Henrÿ (eds.), International Handbook of Cooperative Lam, Heidelberg, Springer 2013c, p. 115 et seq.

A. Fici, "La cooperación entre cooperativas en el Derecho italiano y comparado", 48 Boletín de la Asociación Internacional de Derecho Cooperativo, 2014, p. 103 et seq.

E. Gadea, F. Sacristán \& C. Vargas Vasserot, Régimen jurídico de la sociedad cooperativa del siglo XXI, Dykinson, Madrid 2009.

C. Gide, Consumers' Co-operative Societies [a translation of the third French edition published in 1917], Co-operative Union Limited, Manchester 1921.

H. Hansmann, The Omnership of Enterprise, Cambridge, Belknap HUP 1996 [(1st paperback edition, 2000].

H. Hansmann, "All firms are cooperatives-and so are governments", 2 Journal of Entrepreneurial and Organizational Diversity 2, 2013, p. 1 et seq.

H. Hansmann \& R. Kraakman, "The Essential Role of Organizational Law”, 110 Yale Law fournal, 2000, p. 386 et seq.

H. Hansmann \& R. Kraakman, "The End of History for Corporate Law", 89 Georgetomn Law Journal, 2000-2001, p. 439 et seq.

H. Henrÿ, "Sustainable Development and Cooperative Law: Corporate Social Responsibility or Cooperative Social Responsibility?", University of Oslo Faculty of Law Research Paper n. 2012-23, 2012, available at <www.ssrn.com>.

H. Henrÿ, "Finland", in D. Cracogna, A. Fici \& H. Henrÿ (eds.), International Handbook of Cooperative Law, Heidelberg, Springer, 2013, p. 373 et seq.

J. Jang, "Republic of Korea", in D. Cracogna, A. Fici \& H. Henrÿ (eds.), International Handbook of Cooperative Lam, Heidelberg, Springer 2013, p. 653 et seq.

R. Kraakman, J. Armour, P. Davies, L. Enriques, H. Hansmann, G. Hertig, K. Hopt, H. Kanda \& E. Rock, The Anatomy of Corporate Law. A Comparative and Functional Approach, 2nd ed., New York, OUP 2009.
A. Kurimoto, "Japan”, in D. Cracogna, A. Fici \& H. Henrÿ (eds.), International Handbook of Cooperative Lam, Heidelberg, Springer 2013, p. 503 et seq.

H.-H., Münkner, Co-operative Principles and Co-operative Lam, Bonn, Friedrich-Ebert-Stiftung 1974 [4th reprint 1981].

H.-H. Münkner, Ten Lectures on Co-operative Law, Bonn, Friedrich-Ebert-Stiftung 1982.

H.-H. Münkner, "Germany", in D. Cracogna, A. Fici \& H. Henrÿ (eds.), International Handbook of Cooperative Lam, Heidelberg, Springer 2013, p. 413 et seq.

H.-H. Münkner \& C. Vernaz, Annotated Co-operative Glossary, Marburg, Marburg Consult for Self-Help Promotion 2005.

M. Pantaleoni, "Esame critico dei principi teorici della cooperazione", Giornale degli economisti, 1898, pp. 202 et seq., 307 et seq.

C. Sanchez Bajo \& B. Roelants, Capital and the Debt Trap. Learning from Cooperatives in the Global Crisis, Basingstoke, Palgrave MacMillan 2011.

G. Santini, "Tramonto dello scopo lucrativo nelle società di capitali", Rivista di diritto civile I, 1973, p. 151 et seq.

I. Snaith, "United Kingdom”, in D. Cracogna, A. Fici \& H. Henrÿ (eds.), International Handbook of Cooperative Lam, Heidelberg, Springer 2013, p. 735 et seq.

J. Stiglitz, "Moving beyond Market Fundamentalism to a More Balanced Economy", 80 Annals of Public and Cooperative Economy 3,2009 , p. 45 et seq.

F. Taisch \& A. Jungmeister, "Der Beitrag der genossenschaftlichen DNA als Basis für Wachstum und Differenzierungsstrategien", in J. Laurinkari, R. Schediwy \& T. Todev (eds.), Genossenschaftswissenschaft zwischen Theorie und Geschichte: Festschrift für Prof. Dr. Fohann Brazda zum 60. Geburtstag, Bremen, EHV Academicpress 2014, p. 381 et seq.

C. Torres Morales, "Peru", in D. Cracogna, A. Fici \& H. Henrÿ (eds.), International Handbook of Cooperative Lam, Heidelberg, Springer 2013, p. 585 et seq.

G.J.H. van der Sangen, "Netherlands", in D. Cracogna, A. Fici \& H. Henrÿ (eds.), International Handbook of Cooperative Lam, Heidelberg, Springer 2013, p. 541 et seq.

S. Zamagni, "Per una teoria economico-civile dell'impresa cooperativa", Rivista della cooperazione, 2005, p. 31 et seq. 